Tyards Graphic Metamorphoses: Fiquring the Semiosic Drift in the Douze Fables de fleuves ou fontaines

By: Robert E. Campo

Campo, Roberto E. “Tyard's Graphic Metamorphoses: Figuring the Semiosic Drift in the Douze Fables de fleuves ou fontaines.” Renaissance Quarterly 54 (Autumn 2001): 776-800.

Made available courtesy of University of Chicago Press:

http://www.jstor.org/stable/1261924

***@) Renaissance Society of America. Reprinted with permission. No further reproduction is authorized without written permission from Renaissance Society of America \& University of Chicago Press.***

\begin{abstract}
:
Pontus de Tyard, a lesser-known member of the Pleiade poets of mid-sixteenth-century France, was deeply influenced by the concerns of his comrades and contemporaries about the elemental remoteness of all "reality" and the resulting "semiosic drift" undermining any attempt to denote it. He expresses this preoccupation during the mid 1550s, in the Douze Fables de fleuves ou fontaines, his long underrated collection of twelve mythological fables, each accompanied by directions for a fable-based painting and an explanatory sonnet. Like the author's more highly regarded Discours du temps from the same years, the Douze Fables registers traces of not only the "strong" hermeneutic paradigm of the hermetic Neoplatonic tradition, but also the anxietyridden mannerist aesthetic of the period.
\end{abstract}

Keywords: Sixteenth century French poetry | Renaissance art | Fables | Pontus de Tyard | Literary analysis

***Note: Full text of article below 


\title{
Tyard's Graphic Metamorphoses: Figuring the Semiosic Drift in the Douze Fables de fleuves ou fontaines
}

\author{
by ROBERTO E. CAMPO
}

Ponnus de Tyard, a lesser-knoum member of the Pletiade poess of mid-sixteenth-century France, was deeply influenced by she concerns of his comrades and contemporaries about the clemental remoteness of all "reality" and the resulting "semiosic drift" undermining any attempt to denote it. He expresses this preoccupation during the mid 1550s, in the Douze Fables de fleuves ou fontaines, his long undernated collection of tuelve mythological fables, each accompanied by directions for a frable-based painting and an explanatory sonnet. Like the authar's more highly regarded Discours du temps from the same years, the Douze Fables registers traces of not only the "strong" hermeneutic paradigm of the hermetic Neoplatonic tradition, but also the anxiety-ridden mannerist aesthetic of the period.

Tn a series of essays exploring the complexities of medieval and early modern Lermeneutics, Umberto Eco foregrounds what he describes as the "Hermetic tradition" of the "strong" Neoplatonic hermeneutic paradigm derived from the writings of Nicholas of Cues and the principals of the Florentine Academy, Pico della Mirandola, Marcilio Ficino, and Giordano Bruno. According to this paradigm - whose concerns are as much epistemological, ontological, and theological as they are semiotic - no sign may achieve full semantic presence since all referents are part of a universal network of elemental similitudes emanating from the coincidentia oppositorum and discordia concors of the original infinite One. 'However much a signifier may bear some "natural" relation to its signified (and here the assumption is that any signifier could indeed be found to do so if one were to trace it back to its most ancient origins), a sign can never attain referential univocity because its denotative object necessarily belongs to a web of infinite correspondences in which any single entity in the world points in some measure to every other entity in the world. Eco describes the effect as a "labyrinthine web of mutual referrals" in which all meaning, or truth, is trapped in an endless "semiosic drift": a process of signification based on the "perennial shift and deferral" of any possible semantic plenitude, wherein the "meaning of a given word or of a given thing [is] another word or another thing" and "everything that [is] said is in fact nothing else but an ambiguous allusion to something else."

'Eco's "strong" Neoplatonic paradigm is a distilled version of the original Neoplatonic model, one that the hermetic and cabalistic thinkers of the day derived from an eatreme reading of Pico and the Academicians of Florence. Sec Eco, 23-32.

${ }^{2}$ Eco, esp. 27. It may be noted that Eco departs in some measure from E. H. Gombrich's representation of Neoplatonic linguistics. Whereas the latter insists that the Florentine Aca- 
Previous studies have elucidated symptoms of this drift in the poetry and prose of the Pléiade leaders, Ronsard and Du Bellay. There is little dispute that the mannerist qualities of copia and intertextual and interart contention infusing their works reflect more than the stylistic influences of particular ancient and early modern authors and artists. The tension between multiplicity and unity that imbues their formal and thematic dispositions is also a trace of this fundamental contemporary semiotic and philosophical preoccupation. ${ }^{3}$

A concern about the semiosic drift is similarly a factor in the compositions of the lesser Pléiade authors. The intriguing yet seldom studied Douze Fables de fleuves ou fontaines by the Pléiade late-comer Pontus de Tyard (1521-1605), Lord of the familial estate at Bissy near Mâcon and (beginning in 1578) Bishop of Chalon-sur-Saône, provides a case in pointr. ${ }^{4}$ Composed around 1555 or 1556 , his collection of twelve disparate mythological stories, each followed by the instructions for a tale-inspired painting and a sonnet-epigram destined to serve as explanatory legend to the picture, ${ }^{5}$ has hitherto been regarded in either of two ways. To some, the work would constitute a marginal adjunct to Tyard's oeuvre. In assuming this view they seem readily convinced by the claims of Exienne Tabourot, the lawyer and friend to Tyard who, in his apologetic preface to the first published edition of the manuscript in November 1585, emphasizes the author's humble attitude toward the work. ${ }^{6}$ For these critics, the Douze Fables would above all represent the working papers for a collaborative venture with the French painters or

demy advocated an essentially Cratylistic theory of language, as evidenced by their preoccupation with fanciful etymologies (Gombrich, esp. 170), Eco's position exposes the underlying anxiety in that obsession. From the perspective laid out in his recent study, such lexical source-searching would reflect an apprehension about the semantic instability of language, a need to return to roots in the illusory hope of staying the semiosic drift. By "semiosis," we may henceforth understand the signification process isself, in accordance with the definition proposed by Maryann Ayim.

'For the broadest discussions of the copia concept, see Cave, 1973 and 1979. On the semiosic concerns underlying Ronsard's ekphrastic poetry, see Nash, 143-62, and Ford, 1989. A review of these ideas and others, along with a statement of my own position on Ronsard's place in the interart rivalry of his day, may be found in my book, Ronsard's Contentious Sisters.

${ }^{4}$ On the life of Pontus de Tyard, see Hall, esp. 1-33. See also, Baridon, 1-14.

'All references to the Douze Fables are to the critical edition appearing in Tyard, 1966. 255-77. Citations of the work are likewise derived from this edition and will henceforth be described by an allusion to the part in which they appear $(\mathrm{F}=$ fable; $\mathrm{P}=$ painting; $\mathrm{E}=$ epigram), to page, and where relevant, to verse. All translations are my own.

"According ro Tabourot's dedication. Tyard seems to have felt that the Douze Fables were but an exercise of his unseasoned youth (although he was at least 34 years old when he penned them). In response to what he describes as the author's "feeble excuses" (foibles excu- 
tapestry designers engaged in adorning the Salon des Glaces of Diane de Poitiers' castle at Anet. In this perspective, the work is of interest less for its literary or philosophical import than for its art-historical value, as a specimen of the kind of script employed when poets and artists of the period came together to set the iconographic outlines of an elaborate public performance or a privately commissioned decorative project. ${ }^{\text {? }}$

A second group of readers has made Tyard's tales a more significant part of his writings. Whether or not they served some pretextual purpose for the artists of his day (a matter of some genuine debate, as it happens, since there are no tangible pictorial vestiges of this collaboration nor any references to our author in the contemporary index of Anet designers), ${ }^{8}$ the Douze Fables are unquestionably an enactment of his creative modus operandi. On one level, they would demonstrate the Mâconnais's predilection for loose intertextual imitation, his freehanded, sometimes "vulgarized" appeal to ancient and early modern mythological compendia for conceptual inspiration. ${ }^{9} \mathrm{On}$ another level, the work would distill the poet's abiding attachment to the Petrarchan theme of metamorphosis. For John Lapp and Eva Kushner this attachment is evidence of a pervasive "obsession with the transitory" (hantise du transitoire) that would qualify the piece as essentially "baroque before its time" (baroque avant la lettre). ${ }^{10}$ On yet another level, the Fables would also

ses) for not publishing them earlier, and perhaps in defense of his own alleged decision to purloin the manuscript from Tyard's study at Bragny some thirty years after its composition, Tabourot insists that "as regards your age and profession [which are] so out of keeping with writings of the quality you put forth, that has nothing in common with the period nor the season in which you made them, since it was at a time when one could call it a most honest and praiseworthy exercise ..." (quant à vostre aage et profession trop dissemblables à escrits de telle étoffe que mettez en avant, cela n'a rien de commun à l'eage ny à la saison esquels vous les fistes. d'autant que ce fut en un temps où l'on le pouvoit appeller un treshonneste er louable cxercice... .; 257 , my emphasis). Such pronouncements must be admitted only guardedly, of course, given the popularity of the topos of textual rediscovery and redemption during the period.

${ }^{7}$ This reading has been equally common among art historians and literary critics. Among the art historians, see Roussel, esp. 58, 94-95; and Mayer, 28. Among the literary critics, see Baridon, 66; Chamard, 3:144; Yates, 135-39; Lebègue, esp. 118; and Kushner, 1978, 346-48. Collaborative scripts of this kind are otherwise considered by Fenoaltea, 7-26.

"See Hall, 23.

"Cf. Hall's comments on Tyard's "technique of [mythological] vulgarization" (62; cf. 103). Philip Ford continues this line of thinking with an emphasis on the resulting "abstruse nature" of Tyard's sources (1997. 13-16, esp. 16).

${ }^{10}$ Although Lapp is the first to draw this conclusion (in Tyard, 1966, xliii), Eva Kushner reprises the idea $(1978,348)$. See also Kushner's remarks on the baroque quality of the theme of inconsistency in the Discours du temps (1986, 225). Another critical discussion of Tyard's metamorphoses appears in Hélène Nais's lexicographical study of the theme (15-25, esp. 22). 
inscribe a challenge to the standards of conventional ekphrastic poetry. From a stylistic inspection of the sonnet-epigrams, Jan Miernowski has identified an effort to surpass the mimetic "illusion of a vision" (illusion d'une vision). Tyard's poems would instead stand apart from the paintings they accompany in order to assume "the function of a commentary that weaves the unifying web of the whole, that enriches the psychological significance of the canvases [and] which ... is indispensable to the understanding of the work." ${ }^{n 1}$

Thus reasons mount to restore the Douze Fables to a place of prominence in Tyard's writings. Indeed, in the present essay I should like to demonstrate that the work is no less significant than, and has deep conceptual connections to, the author's already much appreciated Discours $d u$ temps, de l'an, et de ses parties, his treatise on time, also written in 1555 or 1556 , and which stages a fictionalized trialogue between Tyard himself (as Pontus, the speaking "I" [je]), the celebrated Lyonnais poet, Maurice Scève, and the "diligent observer of religion" (diligent observateur de la religion), Hieromnime. Others have recognized a similar interest in the theme of time in both works. ${ }^{12}$ However, the study that follows goes further in proposing that, like the Discours, the Fables may be regarded as a testimony to the trepidations Tyard experienced upon awakening to the profound metaphysical and aesthetic implications of the semiosic drift. In this regard the water stories would join the philosophical meditation in announcing a conceptual turning point in the author's career. Though, where scholars have previously regarded this shift as a departure from all Platonic influences, ${ }^{13}$ I would suggest that Tyard moves toward the most radical faction of that philosophy as it is distilled in the "strong" Neoplatonic hermeneutic paradigm. Finally,

In this case, however, the textual focus is the Erreurs amoureuses, and the critic offers no reflection on the possible baroque affiliations of the phenomenon. For more on the links between metamorphosis and the baroque, see the various essays compiled by Giscle MathieuCastellani. Michel Jeanneret has also offered a perspective on the idea of metamorphosis in the sixteenth-century, though he does not dwell on the links between that notion and the period styles of the time (see note 61, below).

"Miernowski, 19 (my translation): ". . . la fonction d'un commentaire qui tisse la trame unificatrice de l'ensemble, qui enrichit la portée psychologique des toiles [et] qui ... est indispensable à la compréhension de l'oeuvre"; see pp. 12-22 for his discussion. I draw a similar conclusion in the case of Ronsard's ckphrastic poetry (Campo, 96-115 and passim).

${ }^{12}$ Kushner, 1978, 348.

${ }^{13}$ For Eva Kushner, the Discours would constiture "a hinge between the two principal periods of Tyard's thought" (une charnière entre les deux périodes principales de la pensée de Tyard): the Platonic first part (1549-1555/56) and the subsequent period of cosmological relarivism effected (according to this criric) by the Copernican revolution (1556-1562 and after) (1986, 211-29, esp. 212-13 and 224-29). On Tyard's Platonism in general, see Kushner, 1972. 
given the tensions and anxieties that underlie that discovery, and in light of the stylistic features that signal them, I would argue for a reevaluation of the proto-baroque classification of the Fables. A reconsideration of the evidence reveals a work that conforms squarely to the overarching mannerist aesthetic of mid-sixteenth-century France.

Much has been said about how the Discours du temps marks a shift from faith to skepticism in Tyard's life and career. Although this turn may well have some connection to the personal emotional blow he suffered at the close of his relation with the original Pasithée, the irresistible object of his adoration throughout the Erreurs amoureuses (1549-1555) and the first and second Solitaire (1552 and 1555, respectively), it likewise coincides with what Kathleen Hall has called the "rising tide of skepticism" and crisis of "free-thinking" shaking the foremost Pléiade authors and the Neoplatonic circles with which Tyard was in contact during the mid $1550 \mathrm{~s} .{ }^{14}$ Like Ronsard at that time, he came to reconsider and to doubt a host of received ideas, including previous assumptions about the permanence and presence of divine and natural truths and the power of any language to represent them. ${ }^{15}$ And as with the Pléiade leader, Tyard was deeply affected by the Hermetic theories of semiosis expressed in Neoplatonic commentaries like the Heptaplus, Pico's study of Scriptural hermeneutics otherwise known as the Sevenfold Narration of the Six Days of Genesis. ${ }^{16}$ Traces of this hermetically inspired skepticism can be de-

${ }^{14}$ Hall, 139-40. Hall likewise explores the more personal dimensions of this crisis. She especially notes Tyard's "Elegie à Pierre de Ronsard." Written during the same period as the Discours, this poem reports not only the "remoteness" (esloignement) of the Mâconnais' mistress, but also a resulting perception of universal "discord" (discorde) (140-43). For a more scientific explanation, see Kushner, 1986, 212-13, and note 13, above.

${ }^{15}$ Ronsard's anxiety about impermanence in the metaphysical sense becomes especially salient in the Hymnes of 1555-1556. Henri Weber associates this uncasiness with the poet's overall "nostalgia for the immutable" (nostalgie de l'immuable) at that point in his career (3351, esp. 35). The theme of fleeting time in the Hymnes has been further explored by Françoise Joukovsky (53-82). On Ronsard's preoccupation with the semiosic drift, particularly in relation to the semiosic shortcomings of painting and the corresponding strengths of poetry, see Campo, esp. $90 \mathrm{ff}$. For a perspective on the importance of semiosic doubt in Pléiade poetics in general, see the rendering of Claude Fauchet's misgivings in Louis Le Caron's Ronsard, ou de la Poësie. Dialogue IV (294). Hall offers further reflections on this issue (139-40).

${ }^{16}$ Although one finds no explicit textual link between Pico's and Tyard's intellectual swerve at this time, there can be little doubt that the Mâconnais had a broad understanding of the major semiotic concepts that issued from the Florentine Academy, if only (in some instances) through intermediary sources such as Francesco Giorgio's De Harmonia Mundi (1525). Cf. Hall, 60-104, esp. 94ff. We shall promptly return to this influence below. 
tected in both the Discours du temps and the Douze Fables de fleuves ou fontaines. In the second case, however, that influence takes on a poetic and aesthetic dimension absent from the author's contemporary treatise on time.

The most elemental inscription of this indebtedness is Tyard's anxiety over the notion of a universe of infinite correspondences, the metaphysical concept from which the idea of the semiosic flow will derive. Pico describes the essence of this universe of "hidden alliances and occult affinities" in the second proem of the Heptaplus (79). His famous disquisition ponders the relatedness of the three worlds of existence known to antiquity (the corruptible sublunary world, the celestial world, and the invisible angelic world) in the context of a reflection on the science of allegorical interpretation:

It should above all be observed ... that these three worlds are one world ... because whatever is in any of the worlds is at the same time contained in each, and there is no one of them in which is not to be found whatever is in each of the others.... Truly, whatever is in the lower world is also in the higher ones, but of a better stamp; likewise, whatever is in the higher ones is also seen in the lowest, but in a degenerate condition and with a nature one might call adulterated. ${ }^{17}$

Although Pico may have regarded this principle of universal affinities as a foundation for subsequent arguments about the underlying naturalness of all modes of symbolism (verbal and visual), in the Discours du temps and the Douze Fables Tyard takes it in the "strong" Neoplatonic, hermetic way - that is, as the basis for his anxious reflections about universal movement and metamorphosis. By virtue of the unlimited relatedness of the multiple realms of existence no thing is ever uniquely itself; its ontology is forever deferred in an endless network of potential correspondences and thereby remains, from any one perspective, in an apparent state of constant flux and transformation.

In the Discours, the very rationale for writing the treatise is openly affiliated with this concern. The dedicatory epistle to Henri III in the 1578 edition plainly locates the motivation for studying time - "that marvelous measure of the periods and processes of all things that one calls Time"18 in a longing to understand, and thus to contain and tether, the constant inconstancy of the heavens:

If there is anything in Nature worthy of careful consideration, it is, in my opinion, the admirable movement and graceful harmony of the celestial bodies, embellished with the most resplendent light and endowed with the most enduring corporal perfection. This is so truc that if ever noble souls arose in

\footnotetext{
$167 \mathrm{ff}$.

17lbid., 77. For more on Pico and the Neoplatonic concept of allegory, see Gombrich,

I" "celle esmerveillable mesure des periodes, \& cours de toutes choses, que l'on nomme le Temps."
} 
contemplation of some excellence, the Heaven seems to me to have been its most commendable object, the beauty, splendor, and diverse movements upon which they [the noble souls] have always been invited to employ their most diligent observation and scrupulous study, in order to know the constant inconstancy and well ruled diversity of its ordinary processes. ${ }^{19}$

The air of optimism in these lines swiftly dissipates in the trialogue that follows. Tyard soon admits that perhaps it is hopeless to find permanent rule and order amid the "diverse movements" (divers mouvements), "constant inconstancy" (constante inconstance), and vast "diversity" (diversité) of creation. Universal harmony is forever undermined by universal discord; the concordia is ineluctably and frustratingly inseparable from the discordia.

If there is any incontrovertible truth, we soon learn, it is that everything is in perpetual movement and transformation. Pontus, the actor-interlocutor, offers precisely this observarion in his preamble to the philosophical treatise, a remark that also introduces a reflection on the nature of the "fable" that will have particular relevance to our reading of the twelve water stories:

The one who first said that man's life is aptly comparable to the fable portrayed in a tragedy or a comedy seems to me to have described in full color and with singular diligence the state of our living, so inconstant and uncertain that a fable (however fabulous it might be) seems to me no less endowed with truth in its true essence than may be found in ourselves. . . The ages of some people in certain years, indeed from one day to the next, or from hour to hour, transform our person, our health, our morals, and affections. But is there to be found an actor of a tragedy who disguises himself in more diverse clothes .... trying to portray himself in such a way that, he thinks, will ply people's eyes more favorably, even though he feels no essential constancy from which he may assign himself a name, if not that he is a diligent representor of that which in no way belongs to him? Is one to be found (I mean) who disguises himself more variably than we, transformed from moment to moment, whether through the true mutation of our opinions or, often, by feint and dissimulation? . . . the course of our years, spent in happiness, in unhappiness, in joy, in mourning, now in

"Tyard, 1578: "S"il y a aucune chose en la Nature, digne de consideration diligente, c'est, à mon advis, l'admirable mouvement, \& la gracieuse harmonie des corps celestes, embellis de la plus resplendissante clairté, $\&$ douez de la plus durable perfection corporelle. Tellement que si jamais les ames genereuses se sont elevees en contemplation de quelque excellence, le Ciel me semble en avoir esté le plus louable sujet, la beauté, splendeur, \& divers mouvements duquel les ont toujours invitees d'employer leur plus soigneuse observation, \& curieuse estude, pour cognoistre la constante inconstance, $\&$ bien reglee diversité de ses cours ordinaires" (n.p.). Subsequent references to, or citations of, the Discours will be to the 1578 edition; again, the translations are mine. 
one mood, then in another (like comedians who make various entrances) scarcely leaves us in a durable state of being .... ${ }^{20}$

The theatrical allusions in this statement do more than provide a convenient transition into the staged presentation that follows; they also highlight the essential link Tyard draws between the metaphysical and the mimetic. Moreover, through the example of fables and their theatrical enactment, he drives home his point about the evanescence, even inessentiality, of life and the universe. Like the actor who plays different roles from one scene or performance to the next, and therefore suffers no true selfhood ("he feels no essential constancy from which he may assign himself a name" $),{ }^{21}$ we in our lives are doomed to don a kind of fabular disguise from one moment to another, because each new moment, as a source of new mutations, defers any chance for a fixed identity ("the course of our years ... scarcely leaves us in a durable state of being"). ${ }^{22}$ It is from this position of frustration that the author then asks the question that truly motivates the polemic: "Thus could we not arrest this life on the plinth of some solid and square certainty? It would be necessary (I believe) to clip the wing of Time, whose invisible, indeed imperceptible, flight continually carries away all of our assurance" (1v). ${ }^{23}$ But as we have already intimated, the answer to this query is scarcely reassuring: such a "wing-clipping" lies well beyond our powers. Thus, notwithstanding the erudite philosophical, scientific, and etymological discussions that ensue (a section inspired in large part by the 1541 De Annis et mensis caeterisque temporum partibus of the Italian mythographer Lilio Gi-

20"."Celuy qui dit premier, la vie de l'homme estre pertinemment comparable à la fable representee par une Tragedie, ou Comedie, me semble avoir depeint de toutes couleurs, \& avee singuliere industric, l'estat de nostre vivre, tant inconstant \& incertain, que fable (tant soit elie fabuleuse) ne me semble moins avoir de verité en vraye essence qu'il s'en rencontre en nous. ... Les âges de certains en certains ans, voire d'un en autre jour, ou d'heure en heure nous transforment la personne, la santé, les meurs, \& les affections. Mais se voit-il joueur de Tragedie, qui en plus divers habits se desguise ... taschant de se contrefaire ainsi qu'il pense plus favorablement flechir les populaires yeux, bien qu'il ne sente aucune essencielle constance de laquelle il sceust se surnommer, sinon qu'il est industrieux representeur de ce dont il r'a rien? S'en voit il (veux je dire) qui se desguise plus variablement que nous, transformez de moment en moment, ou par vraye mutation de nos opinions, ou, souvent, par feinte \& dissimulation?... I e cours de nos ans, escoulé en heur, en malheur, en joye, en dueil, maintenant d'une humeur, \& puis d'une autre (comme les personnes Comiques font diverses sorties) nous laisse si peu en un estre durable ...." (1-lv).

21 "il ne sente aucune essencielle constance de laquelle il sceust se surnommer"

${ }^{22}$ "le cours de nos ans... nous laisse si peu en un estre durable"

23 "Done ne sçaurions-nous artester ceste vie sur le plinthe de quelque solide \& cubique seureté? Il faudroit (croy-je) retrancher l'aile du Temps, duquel l'invisible, voire l'insensible fuite, entraine continucllement toute nostre asseurance." 
raldi of Ferrara), our author-actor is compelled to conclude with a telling (mis-)citation from Euripides' Alcestis: "Alas! (I sighed) how much that word of Euripides pleases me: . . . life is not life, but calamity" (32). ${ }^{24}$ Life is a chaotic state of affairs, devoid of even the most transitory ontological identity ("la vie n'est point vie"), like the ever-changing universe in which it arises.

The Douze Fables register a similar metaphysical angst. It is figured from the outset, in the very title of the work, which invariably calls to mind the remarks about fables in the Discours. Beyond anticipating the allegorical function of the assembled mythological stories, and so conforming to the more customary sense of "fable" during the period, ${ }^{25}$ the term would also designate an interest in the metaphysical and mimetic problems posed by a universe in flux. The word would likewise hint at the inessential underpinnings of fabular representation, the inconstancy and uncertainty of the world that such tales presume to signify.

This idea is further suggested, both in the title and throughout the twelve stories, by the very preoccupation with "rivers or fountains" (fleuves ou fontaines). ${ }^{26}$ For Tyard, as for poets and philosophers since the beginning of time, water is the quintessential metaphor for the evanescence of creation in the ceaseless course of the temporal flow. One has only to recall the metaphysical musings of the pre-Socratic "crying" philosopher, Heraclitus (ca. 500 B.C.E.), as reported by Plutarch in his De E apud Delphos:

"It is impossible to step twice in the same river" are the words of Heracleitus [sic], nor is it possible to lay hold twice of any mortal substance in a permanent state; by the suddenness and swiftness of the change in it there "comes dispersion and, at another time, a gathering together"; or, rather, not at another time nor later, but at the same instant it both settles into its place and forsakes its place; "it is coming and going." ${ }^{27}$ calamité,"

26"Las! (soupiray-je) combien me plaist ce mor d'Euripide: ... la vie n'est point vie, mais

${ }^{25} \mathrm{Cf}$. Ronsard's Hymne de l'hyver, 12:71-72, verse 70-80: "So in order that the ignorant people may not scorn / The truth after having learned it /I ... I have designed this hymn, imitating the model / Of the fables of Hesiod and those of Homer" (Puis afin que le peuple ignorant ne meprise / La verité cognue apres l'avoir aprise, // . . j'ay tracé cet hymne, imitant l'exemplaire / Des fables d'Hesiode \& celle d'Homere). We shall return to this sense of "fable" below. All citations of Ronsard's works will be described parenthetically by volume, page, and verse in the Laumonier edition; the translations are my own.

${ }^{26}$ "The disjunction "or" (ou) may itself be a further hint at the unstable essence of the poet's topic. One may contrast this facet of the title with the CONjunction "and" (que) in the Pseudo-Plutarch's De Fluviorum MontiumQUE Nominibus (my emphasis), one of Tyard's primary models for the Fables (see below).

${ }^{27}$ Plutarch, 1936, 5:240-41 (392B-C). 
For Tyard's Pléiade colleagues, too, the aqueous image would retain all of its original implications. Ronsard, for example, will raise precisely this idea in his Aristotelian metaphysical explanation of death in the Hymne de la Mort from the same period as the Mâconnais's water stories:

That which was remakes itself, everything flows like water,

And nothing under Heaven is seen anew:

But the form is changed into another that is new,

And that change is called living in the world,

And DYING, when the form gives way to another. ${ }^{28}$

The Pléiade leader will revive the image in the lyric setting as well. Some five years after the hymn to death, he will evoke the transitoriness of water amid his poignant portrayal of the tortured lover's ephemeral lot in the famous Petrarchan-style ode of 1560, "When I am twenty or thirty months" (Quand je suis vint ou trente mois):

Waves, you course without end,

And you carry and return

Your waters at a pace that does not tarry,

And I, without tarrying long,

Make away at night and in day,

But like you I do not return. ${ }^{29}$

The Mâconnais himself plays upon this metaphor in the Discours $d u$ temps. At the start of Scève's review of the conceptual distinctions between "eternité," "le temps," and "Aevum," Tyard indulges in a poignant aside about the stream that flows into the canal encircling the insular garden where the deliberations are unfurling:

such considerations seem to me quite difficult to understand, especially for us, who feel time flowing more palpably than this water (gesturing to a small and clear stream, which was flowing opposite the canal, encircling the island of my garden). ${ }^{30}$

The "ruisseau" is more than a detail of the scene's theatrical backdrop; it is also more than a concession to the locus amoenus topos (where a stream en-

28"Ce qui fur se refaict, tout coulle comme une cau, / Et rien dessous le Ciel ne se void de nouveau: / Mais la forme se change en une autre nouvelle, / Et ce changement là, vivre au monde s'appelle, / Et MOURIR, quand la forme en une autre s'en va" (8:178, verses 325-29).

29 "Ondes, sans fin vous promenés, / Ex vous menés \& ramenés / Vos flots d'un cours qui ne sejourne, / Et moi, sans faire long sejour, / Je mien vais de nuit \& de jour, / Mais comme vous je ne retourne" (7:99, vv. 25-30).

30" telles considerations me semblent de bien difficile apprehension, à nous principalement qui sentons couler le temps plus sensiblement que ceste eau (monstrant de la main un petit \& clair ruisseau, qui couloit contre le canal, environnant l'isle de mon jardin)" (2). 
dures as one of the traditional elements) that otherwise affords the topographical and conceptual context for the debate. ${ }^{31}$ Rather, it is a substantial part of the discourse, virtually a fourth - albeit muted - actor in the play whose special role amounts to being an ever-present reminder of the inexorable volatility of the universe, and here especially, of time, the topic that preserves the assembly of players at the geographical site indicated.

The same is essentially true of the rivers and fountains of the Douze Fables. Only, as the title indicates, here the water assumes an even more central role. In addition to being the principal narrative and iconographic unifier of the collection, water often fully doubles and/or rivals the main characters in the stories. This is particularly true for the "fleuve" pieces, which comprise $2 / 3$ of the work (eight out of the twelve tales). On two occasions, for example, the principal protagonists wholly metamorphose into the rivers that take their names. In the first fable, it is Bacchus's wet nurse, the nymph Clytorie, who changes form when she literally melts into tears ("Elle, fondant en pleurs. .."; E:259, verse 13), and thereupon into the waters of the "fleuve Clytorie," in a selfless act to rescue her innocent charge from the fiery fate that consumed his mortal mother, Semelé, the naive victim of Jupiter's "thunder-striking" (foudroyante; F:258) embrace. A watery transfiguration is likewise the fate of Selemne, the principal victim in fable 3. As the youthful cowherd succumbs slowly to the mocking rejections of his former lover, the cold-hearted nymph Argire, a sympathetic Venus intervenes to help him forget his amorous anguish by transforming him into a river whose waters acquire amnestic powers to ease the torments of love like his own: "He, finally glutted with loving, also has his fill of living: / And for the oblivion of Love, Venus slips him into the water / That washes and extinguishes every amorous martyr" (E:263, verses 12-14). ${ }^{32}$

In the seventh fable, on the other hand, the river Inde enters the story as both double and rival of the main character. The aqueous flow, known originally as the Mausol (Mausolus), is simultaneously the twin and adversary of the man who supplies its new name. During an elaborate celebration of the Bacchanalian mysteries, the young Inde (Indus) forces his illicit lusts upon Damalcide (Damasalcidas), the daughter of king Oxialce (Oxyalcus):

F: “ $\ldots$ a young man named Indus, conveniently encountering Damasalcidas (daughter of king Oxyalcus) ravished her and took his pleasure with her."

P: "In another place would be Damasalcidas, whom Indus would ravish...."

"On the locus amoenus topos and other characteristics of the Renaissance dialogue, see Kushner, 1982 and 1996.

32. "Luy en fin soul d'aymer, de vivre aussi se soule: / Et pour l'oubly d'Amour Venus en eau l'escoule / Qui lave et qui estaint tout amoureux martire." 
E: "The young Indus, appeasing a passion that gnaws at him,

Renders Damasalcidas captive to his heated desire." 33

On learning of the outrage, the young woman's royal father immediately sends out a band of soldiers to stalk and kill the vile ravisher. The resulting chase eventually wears down the fleeing criminal, who in exhausted desperation, chances to elude his pursuers by crossing the Mausolus. The attempt proves fatal, however, as the fatigue-impaired swimmer is quickly overcome and drowned - though not, it is important to emphasize, by the breadth or depth of the water he has challenged. Instead, Inde is defeated by the intense force of the river's currents, by the "cours de l'eau trop roide" (E:269, verse 11; my emphasis) and "violent" (P:269; my emphasis). Hence the rapist is undone by qualities of the water that not only match his own ferocious violence during the commission of his crime ("Inde . . . la for f̧a ..."; my emphasis), but that also recall the attribute of irresistibility associated with the inexorable universal flow.

The idea of instability is no less plainly figured in the poet's already noted preoccupation with metamorphoses. While reminiscent of the mutations of frustrated lovers one finds in Tyard's earlier poetic appeals to Ovid, Petrarch, and the Neo-Petrarchans, in the Douze Fables these transformations speak also to an acceptance of the potential or actual ontological mutability of existence. An inspection of the work finds six cases of metamorphosis in all, a number that includes the two instances related previously. What strikes us now about Tyard's accounts, though, is the fact that all the transformations continue to privilege the role of water, and thus the temporal and universal flow, regardless of what the protagonists become (whether water or some other material entity). What is more, in all the cases but two, the poet has gone well beyond his sources to insert the metamorphosis references.

In the first regard, we discover that if the characters do not properly turn into rivers (as they do in the tales of Clytorie and Selemne), they must at least be immersed therein for the change to take place. In the "Sixiesme Fable du Fleuve Araxe," for instance, the grief-stricken king of Armenia becomes the araxa plant only after throwing himself into the waters bearing his name: "Into the river bearing his name, beyond hope he threw himself: I Turned into the araxa plant..." (E:268, verses 10-11). ${ }^{34}$ In fable 7, too, it is not until Inde plunges into the Mausolus that he becomes the stone that will

${ }^{3} \mathrm{~F}$ : "... un jeune homme nommé Inde, rencontrant à propos Damalcide (fille du Roy Oxialce) la força, et en fit son plaisir." P: "En un autre endroit seroit Damalcide, laquelle Inde forceroit. ...."E: "Le jeune Inde, estaignant une ardeur qui le ronge, / Rend à son chaud vouloir Damalcide captive" (verses 3-4), (268-69).

34"Au fleuve de son nom, hors d'espoir s'est jetté: / Tourné en l'herbe Arax ...." 
render the "vigor" (vigueur) of all would-be ravishers "soft and cold" (molle et froide; E:269, verse 14). Likewise, in fable 9 Salmace does not blend with Hermaphrodite before the bashful youth has entered the river for a bath: "Hermaphrodite ... entered into the stream to bathe; there Salmace rushed ... and they were so conjoined that their assembled bodies became one" (F:271). ${ }^{35}$ And in fable 11, Strymon, the inconsolable friend of the murderously betrayed Rhesus, is transformed into the stone called Pausilype, "which erases all solicitude" (qui efface toute solicitude; F:274), only after throwing himself into the Palestine river: "Seeking some comfort that might erase his great sorrow, / $[\mathrm{He}]$ casts himself into the Palestine from a deadly cliff" (E:275, verses 7-8). ${ }^{36}$

As for Tyard's authorial enlargements, we discover that only fables 3 and 9 have antecedents that make mention of a metamorphosis. In the Achaia entry of the Description of Greece (7.7.23.1-2), the source for the story of Selemne and Argire, Pausanias makes a fleeting yet clear reference to the mutation: "So Selemnus, deserted by Argyra, died of love, and Aphrodite turned him into a river. ${ }^{37}$ Similarly, in Metamorphoses 4.285-388, the source for the story of Salmace and Hermaphrodite, Ovid carefully reports the divinely effected transmutation whose product is the dual-sexed creature that bears the boy's name:

For their two bodies, joined together as they were, were merged in one, with one face and form for both. As when one grafts a twig on some tree, he sees the branches grow one, and with common life come to maturity, so were these two bodies knit in close embrace: they were no longer two, nor such as to be called, one, woman, and one, man. They seemed neither, and yet both. $(4.373-79)^{38}$

By contrast, the sources for the remaining four stories give no indication that a metamorphosis ever comes about. Indeed, even though it is a principal subtext for much of the Clytorie story (fable 1), Ovid's tale of Semele and Bacchus in Metamorphoses 3:254-315 forgoes all reference to the wet nurse extolled by Tyard (acknowledging only that the prematurely delivered baby was tended by Ino and the girls of Nysa), to say nothing of a description of her mutation. ${ }^{39}$ The Pseudo-Plutarch's De Fluviorum Montiumque

35 "Hermaphrodite ... entra dedans Ie fleuve, pour se baigner: là accourut Salmace . . e et furent si conjoints, que leurs deux corps assemblez, devindrent un."

${ }^{36}$ "Cherchant quelque secours qui son grand dueil efface, / S'eslance en Palestin d'un mortel precipice."

${ }^{37}$ Pausanias, 3:322-23.

${ }^{38}$ Ovid, 1:204-05.

${ }^{39}$ The only mention of an aqueous effusion similar to Tyard's appears in Metamorphoses 15.322-28. This is Ovid's account of Clitor's fountain, a spring that shares properties with 
Nominibus is equally evasive about transformations in the stories that inspired fables 6, 7, and 11. Suffice it to say that although the Greek author implies a causal connection between the drowning of the protagonists and the appearance of the plant and rocks that will bear the qualities associated with their travails, he offers no hint of a metamorphosis. ${ }^{40}$ Manifestly, Tyard has his own reasons for such substantial elaborations: reasons which, as we have already seen, would have close affinities to his own metaphysical notions - and anxieties - about a universe in flux.

His apprehensions about the semiotic ramifications of this universe are equally prominent. Again, they represent a significant point of thematic convergence between Tyard's Fables and his discourse on time. First, there is their common concern about the unnaturalness - or rather, arbitrariness - of verbal signification. Although the Discours forgoes an explicit excursus on the issue, it is effectively encoded in the multiple and lengthy reflections on the problematic origins and meanings of the terminology associated with time. The interlocutors are continually deliberating how different cultures have offered their own ways of measuring and signifying the temporal flow, and how even when these ways have had some (apparent) basis in the observable workings of nature, ${ }^{41}$ substantial disparities have arisen. During a pause in the discussion about the hourly divisions of the day, and specifically about the diverse ways the beginning of the day has been defined throughout the centuries, for example, Pontus is loath to admit that "Here ... arises a difficulty: for all nations have not been, and still are not today, in agreement in the matter of such suppositions" (7 v) ${ }^{42}$ Thus, as the truth is forever shifting, so too is the signified of any signifier, and by extension, the semiosic (or signifying) process in general.

This idea is otherwise painstakingly represented in one of the longest discussions of the treatise (occupying pages 16-21, hence about one-fifth of the work), the debate about the idiosyncratic etymological derivations of the

the flewve of Clytoric: "Whoever slakes his thirst from Clitor's spring shuns the wine-cup and abstemiously enjoys pure water only ..." (2:386-87).

${ }^{40} \mathrm{CF}$. De Fluviorum, tales 11 (Strymon), 23 (Araxes), and 25 (Indus): Plutarch 1905. 5:491, 506, 508-09.

"Cf. the case of "Natural hours" (heures .. . Naturelles), which Pontus describes as "measured by the mouvement (whether in descent or elevation) of fifteen degrees from the ecliptic" (mesurees par le mouvement (soit de descente ou elevation) de quinze degrez de l'Ecliptique; 6ff.).

${ }^{42 "} \mathrm{lci}$... surnaist une difficuleć: car toutes nations n'ont esté \& ne sont encores aujourdhuy d'accord en l'ordre de telles supputations." 
names of the twelve months. Scève's fanciful speculations on the origins of the word "February" (Fevrier) are typical:

[F] or the even-number [of days, there is the] following month, named Februarius by the Latins, February by us, and $\dot{\epsilon} \lambda a \phi \eta \beta 0 \lambda t \grave{\omega} \nu$ - by the Athenians, who in this month hunted deer (you know that this is Ě $\lambda a \phi o \zeta$ ) in memory of Diana, their titular goddess, and in whose name the festivals were celebrated. Or better seems the reason drawn from the fact that during this time the stag sheds his coat and disarms his head in order to reinforce it with a new set of antlers. But the Latins deduced this name Februarius from Februum, meaning, among the Sabines, wood, branches, and all that was necessary for purification sacrifices. Or (with Macrobius) from the god Februus, because he was invoked in this month, for the processions made with the intention of purging the sins of the people; or from Juno - "Februelle," to whom the Romans dedicated this month of Lupercales, and celebrated some funerary obits in consideration of the repose of the dead ..... ${ }^{43}$

Notwithstanding the imprint of Giraldi's De annis on these musings, the Mâconnais has gone beyond his source by weaving the Ferraran mythographer's onomastic observations into a broader demonstration of the arbitrariness of language and the insubstantiality of the semiosic process.

Such linguistic concerns are likewise at the core of the Douze Fables. Once again, the term "fable" is a clue. This time, however, its more traditional sense bears witness to the idea. For as noted earlier, the term was usually associated with verbal allegory and hence, by definition, with the process of mediated verbal signification. Tyard's understanding of this association and process is perhaps most succinctly expressed in the Discours, by Hieromnime's theologically orthodox reminder of the religious referentiality of Hesiodic fables: "Hesiod . . . had certainly perused the books of Moses, so prudently enveloping the secrets of creation and the repose of God under the fold of his fables" (11). ${ }^{44}$ The tales in Tyard's Douze Fables

43 “[P] our le nombre pair [des jours, il y a le] mois suyvant, nommé des Latins Februarius, de nous Fevrier, \& des Atheniens $\dot{\epsilon} \lambda a \phi \eta \beta 0 \lambda \iota \dot{\omega} \nu$, qui en ce mois chassoyent les cerfs (vous sçavez que c'est $e^{\lambda} \lambda a \phi \circ \zeta$ ) en memoire de Diane leur deesse rutelaire: \& au nom de laquelle les festes estoyent solennisees. Si meilleure ne semble la raison tiree de ce qu'en ce temps le Cerf se despouille, \& se desarme la teste, pour la renforcer de nouvelle rameure. Mais les Latins ont deduit ce nom Februarius de Februum, signifiant entre les Sabins, la laine, les rameaux, \& tout ce qui estoit necessaire aux sacrifices pour les purifications. Ou (avec Macrobe) du Dieu Februus, pour ce qu'il estoit invocqué en ce mois, aux processions faites en intention de purger les fautes du peuple: ou de Junon Februelle, à laquelle les Rommains [sic] solennisoyent ce mois des Lupercales, \& celebroyent quelques funeraux anniversaires en consideration du repos des morts..." (17).

44"Hesiode ... avoit bien fueilleté les livres de Moyse, envelopant si cautement les secrets de la creation, \& le repos de Dieu sous le repli de ses fables." 
are similarly referential, essentially devoted to exposing the secrets of creation; only, here the creation is an endlessly volatile one, devoid of the "repose of God" (repos de Dieu) posited as the attainable terminus of signification in the remarks of Hieromnime.

Further, there is the fact that, like the Pseudo-Plutarch's De Fluviorum, the Douze Fables take the naming process as their conceptual point of departure. In one and the other work the author explicitly engages in explaining how various natural phenomena obtained their linguistic signifiers. However, what emerges vividly throughout - and this Tyard scrupulously cultivates in the course of adapting his classical antecedents - is that, with the possible exception of the "fleuve Clytorie" (fable 1) and the "fleuve Selemne" (fable 3), the naming process is fundamentally accidental. The waters in question are called what they are called merely because someone happened to jump, fall, bathe, or take refuge in them. Indeed, in a few instances Tyard takes the extra step to remind the reader that the river had a name prior to the one it acquires in the fable. Such is the case for the "fleuve Strymon" (fable 11), known previously as the "Palestin"; and again for the "fleuve Phasis" (fable 5), formally called the "Arcture," a name infinitely more suitable, or rather natural, by virtue of the river's geographical position in "the most northerly elevation" (la plus Septentrionale elevation; P:266), under "the Arctic star" (estoile Polaire), "which is between the legs of Bootes, the northern constellation" (F:265, my emphasis). ${ }^{45}$

The Douze Fables and Discours converge again in their attention to pictorial allegory. The Discours articulates this interest twice. The first instance arises amid an exchange between Scève and Pontus over the iconographic representation of the concept of time on a certain ancient medal:

But as for Time: the smallest parts into which one ordinarily divides it are the hours, bearers (says Homer) of Heaven, and depicted by the Ancients on the head of Jupiter with the Fates, thus signifying that he is sole governor of destinies and dispenser of hours. That reminds me (I remarked) of having seen an ancient medal, on one side of which the image was erased, but on the reverse was plainly marked with a god, flanked on the right by four nymphs, the first crowned with two branches (woven into a triumphal chaplet) laden with flowers and fruits; the second with spikes of whear; the other [third] with vines and grapes; and che fourch, with a branch covered with olives. Someone said they were four Graces beside an Apollo, holding the bow and the arrows in the left hand, denoting that he is prompt in good deeds and slow to harm. But I judged him to be thunder-striking Jupiter (for there was as much the appearance of a

"qui est entre les jambes de Bootes, constcllation Septentrionale" 
thunderbolt as a bow with arrows), as father of all nature accompanied by the four hours or seasons that the Greeks call $\ddot{\omega} \rho \alpha \zeta$, or kapu் $\zeta . .^{46}$

The real object of concern is not whose hermeneutic intuition is right, but the fact that, like the verbal signs employed to denote the phenomena of time, the pictorial symbols are ambiguous enough to invite interpretational dispute. Since its relation to its referent is purely conventional (if only because the referent has no ontology in the world of natural experience), the god image in question could be read as either Apollo or Jupiter, or perhaps neither one nor the other. Pictorial allegory, we learn, is as much a victim of the semiosic drift as verbal allegory.

A similar example of pictorial arbitrariness is raised at the start of Scève's discussion of January. It involves the statuary portraits of Janus, the deity whose name provides the etymological basis for the appellation of the first month of the year:

Thus is he represented by various statues signifying the year. Pliny declares one of them to have been dedicated by Numa, with two faces and having the fingers of the hands bent and positioned in such a way that the number 365 was represented there (for you know that the Ancients designated numbers by signs and positions of fingers), as if meaning by such a number of the days of the full year that he was God of Time. 1 cannot forget a form of statue dedicated to this god, having in the right hand the figure $T$ and in the left $\xi, \epsilon$, signifying by $T$ the number 300 , and by $\xi, 60$, and by $\epsilon$, five. I shall not tell you anything unknown, describing it as a statue having four forms, in consideration of the four seasons; or (no longer for the year, but for this month) holding a key in the hand, signifying him [to be] door-keeper of the year ...."

46 "Mais pour venir au Temps: les moindres parties desquelles ordinairement on le divise, sont les Heures, portieres (dit Homere) du Ciel, \& par les anciens portraites sur le chef de Jupiter avec les Parques, en signifiant qu'il est seul gouverneur des Destinees \& dispensateur des heures. II me souvient (prins-je la parole) d'avoir veu une medaille antique, de laquelle l'image estoit effacee, mais le revers apparent d'un Dieu, accosté à droit, de quatre Nymphes, couronnees l'une de deux branches (enlacees en couronne trionfale) fleuries \& fruitieres; la seconde d'espis de froument: l'autre de pampre \& de raisins: \& la quatrieme d'un rameau chargé d'olives. Quelcun les disoit estre quatre Graces aupres d'un Apollon, tenant l'are \& les fleches en la main gauche, en signifiance qu'il est prompt aux biensfaits $\&$ tardif à nuire. Mais je le jugeay Jupiter foudroyant (car il y avoit autant d'apparence d'un foudre, que d'un arc avec les fleches) accompagné comme pere de toute nature, des quatre heures ou saisons que les

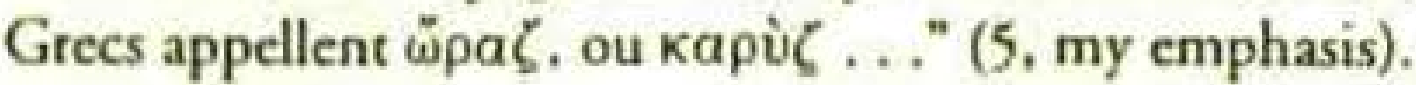

47"Aussi est il representé par diverses statues signifiantes l'an. Une en recite Pline avoir esté consacree par Numa, à deux visages: \& ayant les doigts des mains repliez \& disposez en telle figure, que le nombre 365. y estoit representé, (car vous sçavez que les Anciens notoyent les nombres par signes \& dispositions de doigts) comme entendant par tel nombre des jours de l'an revolu, qu'il estoit Dieu du Temps. Je ne puis oublier une forme de statue, dediee à ce 
Here the issue is less visual hermeneutics than visual mimesis, the possibilities and (especially) problems of imitating a thing or idea by way of visual signs. What stands out is the iconographic abundance to which visual signification may give rise. Even where there is (ostensibly) but one principal referent, that referent may precipitate a multiplicity of visual inscriptions a fact that points again to the arbitrariness of visual signs and the instability of visual semiosis.

In the Douze Fables, Tyard goes further still. In addition to the complexities of visual mimesis, he figures the related difficulties of visual-verbal mimesis, or ekphrasis (what Murray Krieger has defined as the representation in words of a real or imagined work of art), ${ }^{48}$ and verbal-verbal mimesis. The first of these problems (visual mimesis) comes out in the "Description de la Peinture" part of each fable. Of particular interest is the omnipresent use of the conditional mood, as well as the explicit gestures of deference to the discretion of the eventual painter. Both are typified in the instructions for depicting the story about the river Inde in fable 7:

One would have to paint the solemnities and sacrifices of Bacchus.... A few young gir!s would carry covered baskets or small cases; and the priests could be depicted working around some honey-filled vases. ... In another place would be Damasalcidas, whom Indus would violate; or if that act was judged improper to be represented in the painting for this place, one would have to paint Damasalcidas fallen to her knees before King Oxyalcus, her father, to whom she would make her lamentation. Oxyalcus would make a sign of command to some men armed with bows and arrows or other barbarous weapons; and this band would follow the young Indus, who would be seen cast into, and drowning in, the river, whose current would be represented fierce and violent; and Indus [would be] transforming into stone."

Dieu, ayant en la main droite la figure de $T$. \& en la gauche $\xi, \epsilon$, signifiant par $T$, le nombre 300. \& par $\xi$, 60. \& par $\epsilon$, cinq. Je ne vous diray chose incogneue, le descrivant en statue de quatre formes, sous consideration des quatre saisons: ou (non plus pour an, mais pour ce mois) tenant une clef en la main, le signifiant portier de l'annec...." (16).

${ }^{48} \mathrm{Krieger}, 1967$, and also the same critic's more thorough examination of the notion in 1992. For more on ekphrasis during the Renaissance (especially in the poetry of Ronsard), see Lecercle, 20-25; Ford, 1989; Fenoaltea, 28; and Campo, 20-21 and passim.

49" Faudroit peindre les solemnitez et sacrifices de Bachus. ... Quelques jeunes filles porteroient des paniers ou coffins, couvers: et se pourroient peindre les prestres, embesoignez autour de quelques vases remplis de miel. . . En un autre endroit seroit Damalcide, laquelle Inde forceroit: ou, si cet acte estoit estimé mal seant, pour estre representé en la peinture de ce lieu, faudroit peindre Damalcide prosternce à genoux devant le Roy Oxialce son pere, auquel elle feroit sa doleance. Oxialee feroit un signe de commandement à quelques hommes armez 
Jan Miernowski has maintained that the predominance of conditionals serves primarily to "prove that the literary text pre-exists the hypothetical pictorial realization. ${ }^{\text {50 }}$ However, the idea of textual preexistence would also apply to contemporary painting poems like Ronsard's famous Elegie à Janet, peintre du roy (penned in 1554). Yet among the Pléiade laureate's thirty-three injunctions to Janet (François Clouet) for portraying his mistress Cassandre, traces of that mood are rare at best (only one properly belongs to the injunctions themselves) ${ }^{51}$ It seems likelier, then, that Tyard's conditionals have more to do with the semiotic apprehensions we have identified. As the foremost verbal marker of deferred realities, of signifieds that remain merely potential, and so fundamentally absent, until certain prerequisites are met, that verbal mood is a vivid indicator of Tyard's trepidations about the elemental absence - or "elsewhereness" - of all objects and subjects of visual mimesis. The conditionals foreground his worries that any object of imitation (signifieds like the Janus) may invite ever more numerous visual signifiers, or conversely, that any subject of mimesis (signifiers like the image of the Apollo/Jupiter deity) can imply ever more numerous object-signifieds. On another level, the conditionals would also complement an uneasiness about the subjectivity of visual semiosis. The latter idea is otherwise announced in the author's explicit submission to the painter's personal judgment, as in the protasis, "if that act was judged improper" (si cet acte estoit estimé mal seant). It appears again in his repeated use of the disjunctive "or" (ou): "Oxyalcus would make a sign of command to some men armed with bows and arrows or other barbarous weapons." ${ }^{52}$

d'ares er de fleches, ou autres armes barbares: et celle troupe suivroit le jeune Inde, qui se verroit precipité, et se noyant dans le fleuve, duquel le cours seroit représenté roide et violent: et Inde se transformant en pierre" (P:268-69).

50. ... prouve[r] que le texte littéraire préexiste à l'hypothétique réalisation picturale" (12, my translation).

${ }^{51}$ In fact, there are only six instances of the conditional in the two 1555 editions (6:15260; my emphasis): one in verse 71: "But for naught you would have made so beauriful" (Mais pour neant tu aurois fait si beau); two in verse 77: "When he would wish, he would not know what to blame" (Quand il voudroit, n'i sçaurois que reprendre); one each in verses 91 and 92 : "Scarcely would Homer in his verses tell you / What vermilion could equal it" (A peine Homere en ses vers te diroit / Quel vermeillon egualer la pouroit); and one in verse 94: "It would be necessary to paint that of a Grace" (Peindre il faudroit celle d'une Charite). Only the last of these may truly be counted among the poet's invectives. For more on the Elegie à Janer, see Campo, 169-98.

52" Oxialee feroit un signe de commandement à quelques hommes armez d'ares et de fleches, ou autres armes barbares" (my emphasis). In the first case, cf. Tyard's description for the painting of the "Fleuve Chrysoroas" (fable 10): ". . . and he [Chios] would have to be 
For Tyard's preoccupation with visual-verbal and verbal-verbal mimesis, on the other hand, we must return to the relation between the sonnet-epigrams and the painting descriptions and, further, between both of these and the fable text that opens each segment. Miernowski's conclusion about the primacy of the poem over the painting is most helpful here. By supplying the unifying psychological, moral, and narrative substructure of each picture ("la trame unificatrice de l'ensemble"; 19), the sonnet-epigram points to and supplements a substantial semiotic absence in the visual image. Regardless of how detailed a "Description pour la Peinture" may become (and this is often quite extensive, as in the instructions for painting the story of the river Inde, cited above),${ }^{53}$ the implication is that the image must rely upon the verbal meta-commentary to regain a measure of the meaning lost in the drift of visual semiosis. This is not to intimate, however, that Tyard was therefore inclined to believe in the ability of words to stay the semiosic flow, and thus that perhaps he was joining Ronsard as a player on the side of poetry in the ongoing "paragone" rivalry, the contest for artistic supremacy, between the poets and painters of the day. While his Fables may well make an important contribution to this polemic (if only tangentially), they hardly betoken the position of a zealous champion for either art form. On the contrary, Tyard's presentation of verbal-verbal mimesis closely parallels his rendering of visual-verbal imitation: the fables are to the sonnet-epigrams in much the same way that the sonnet-epigrams are to the painting descriptions. In the end, the fable summaries may be regarded as the legends that give meaning to all that follows them, including the poems. They are the pretexts from

laden with gold, at the discretion of the painter, falling into the river amid whose water the gold would be seen rolling" (et faudroit qu'il [Chios] fust chargé d'or, à la discretion du peintre, tombant dedans le fleuve, parmy l'eau duquel l'or se verroit roulant; 273 , my emphasis). In the second case, $\mathrm{cf}$. the painting description for the "Fontaine D'Andre" (fable 2): "One would have to paint ... a woman ... dressed in the skin of a wild goat or a hind's fawn ...." (Il faudrait peindre ... une femme ... vestue d'une peau de chevreuil ou fan de biche ...; 260, my emphasis); the "Fleuve Strymon" (fable 11): "Dolon [would be] clothed in a wolfs skin .... and his head covered with a morion crested with a marten or another such little beast

..." (Dolon [serait] vestu d'une peau de loup ... et couvert la teste d'un morrion cresté d'un furon, ou autre semblable bestion . . .: 274, my emphasis); and the "Lavatoire d'Isis" (fable 12): "Isis may be dressed in the color white and black, or in a long stole or white dress...." (Isis se peut vestir de couleur blanche et noire, ou d'une longue estole ou robe blanche...; 277. my emphasis).

"The full description occupies twenty lines in the Lapp edition. A similar length is attained by the painting instructions for the "Fontaine d'Andre" (fable 2) and the "Fontaine Callirhoe" (fable 4). For the longest account, however, the prize would go to the "Peinture" of the "Lavatoire d'lsis" (fable 12), which comprises fully thirty-one lines of text. 
which the paintings and the verses derive their semantic direction (to say nothing of their very reason for being).

But this is still not to suggest that verbal language, as the medium of the fables, attains the upper hand in Tyard's unstable semiosic universe. For as the complete title of the work makes clear - Douze Fables de Fleuves ou Fontaines, avec la description pour la peinture, et les Epigrammes: Tirees d'Homere, d'Ovide, de Diodore, de Pausanias, de Plutarque, et autres anciens Auteurs (Twelve Fables of Rivers and Fountains, with the Description for the Painting, and Epigrams: Drawn from Homer, Ovid, Diodorus, Pausanias, Plutarch, and Other Ancient Authors) ${ }^{54}$ - the fables all have their own pretexts. They all denote other words - the fables of the ancients - which themselves (Tyard knew only too well) denoted still other words, and so on. Thus the proliferation of pretexts, and more broadly, of signs, is virtually endless, without a fixed point of origin that one could identify as the final locus of semantic presence. Much like their visual counterparts, the verbal signs are doomed to a perpetual semantic equivocity, and thereby to a domain of irreparable falsehood, for as Pontus resolutely affirms in the Discours du temps, "unity is sacred to the truth, as plurality [is sacred] to the lie." 55

The preceding findings suggest several larger conclusions. First, they would decisively abrogate John Lapp's claim about the impenetrability of the Douze Fables in his editorial introduction to the work: "But there are doubtless many relationships and obscure meanings [of the Fables] that the modern reader could no longer detect" (256). ${ }^{56}$ Certainly, the present study makes substantial headway in unveiling the semiotic and philosophical import of the work for the modern reader. Substantial progress has likewise been made in dispelling dismissive assumptions about the derivative nature of Tyard's writings. Kathleen Hall's charge that the Mâconnais is "not a competent

\footnotetext{
${ }^{14}$ Notwithstanding the uncertainties about the authorship of the title (we have yet to determine who actually devised this rambling appellation, Tyard or Tabourot, or perhaps the first publisher of the work, Jean Richer), the point it makes about pretextual indebtedness is orherwise inscribed repeatedly throughout the Fables. Cf. the explicit references to textual antecedents in the painting descriptions for the "Fontaine d'Andre" (fable 2): "thus does Philostratus describe it" (tel le descrit Philostrate"; 260); the "Fleuve Selemne" (fable 3): "according to Pausanius" (au raport de Pausanias"; 262); and the "Lavatoire d'Isis" (fable 12): "such as Virgil and the other poets have described it" (tel comme l'ont descrit Virgile et les autres Poetes"; 276).

55 ". . . l'unité est sacree à verité, comme la pluralité au mensonge" (11, my emphasis).

\$6" Mais il y a sans doute bien des rapports et des significations obscures [des Fables] que le lecteur moderne ne saurait plus déceler."
} 
original thinker" (84) is no longer defensible. Throughout the Douze Fables, Tyard goes well beyond his sources in both word and spirit.

It is further apparent that the water stories deserve at least as much attention as the Discours du temps. Indeed, these works share so many conceptual postures that one should ultimately consider them together, as a diptych on Tyard's newly adopted "strong" Neoplatonic position toward semiotics and metaphysics. And in a related regard, we find that Tyard has even more in common with the Pleiade authors ${ }^{57}$ than was previously believed. Like Ronsard, he is thoroughly familiar with, and embroiled in, some of the thorniest linguistic and aesthetic controversies of his time, including those that intersect contemporary debates about the relative semantic merits of words and images.

Finally, our findings would also dictate a reassessment of previous affirmations about the baroque character of the Fables. Contrary to those claims, we find that the work shows an unmistakable affinity with the mannerist aesthetic of the period. On the most superficial level, there can be no mistaking the mannerist predilection toward multiplicity of form and content. That quality, which John Shearman and others regard as one of the quintessential features of this period style (in both its visual and verbal manifestations), ${ }^{58}$ is as clearly inscribed in the work's inclusion of twelve separate stories as it is in the triadic (hence multiform) structure of each fable. Multiplicity is likewise apparent in the disparate contents of the tales. Notwithstanding the common themes of water and metamorphosis, the assembled stories present a highly diverse array of mythological and legendary personages entangled in a comparably diverse assortment of personal tribulations.

On another level, there is equal evidence of the kind of "allégeance subversive," or conflict-ridden rebellion against the revered model, that Claude-Gilbert Dubois has placed at the center of the mannerist aesthetic. ${ }^{59}$ Besides the textual one-upmanship implied in Tyard's reshaping of

${ }^{57}$ It is true, of course, that recent scholarship has done much to etode the notion that the authors whom Ronsard included in his "Pléiade" (originally, "Brigade") were of one mind on all literary issues, and thus to show that the term "school" must be applied guardedly when referring to them collectively. Nevertheless, there can be little dispute that they all took great pride in being nominated to that brotherhood of poets and that on many central matters (particularly regarding concepts of the poet, language, and imitation) they were more consonant than contentious.

${ }^{54}$ See especially John Shearman's comments on mannerist copia and complexity (esp. 22-23). See also Walter Friedlaender's remarks on figural crowding and compositional "eurythmy" (3-43,60); and Mared Raymond on mannerist "varieté" and "surabondance" (esp. $19-20,25,33)$.

${ }^{59}$ Dubois, esp. 11 and 38. 
the Pseudo-Plutarch's De Fluviorum and Pausanias's Description of Greece, ${ }^{60}$ there is the poet's interstitial recognition of the inadequacy, or impotence, of all mimetic endeavors - especially as they relate to the broader problem of the semiosic drift.

Last, on the matter of metamorphoses, it is again manifest that Tyard remains firmly within the mannerist mode of his day. However common metamorphoses may be in the art and literature of the late-sixteenth and early seventeenth centuries, those that Tyard has figured stop well short of expressing what John Rupert Martin identifies as the "air of epic tragedy" and "intense emotionalism" characteristic of the baroque aesthetic of that later period. ${ }^{61}$ The obsession with the transitory ("hantise du transitoire") identified by John Lapp is ultimately more cognitive than affective; the semiosic anxieties it signals are far more intellectual than emotional. Indeed, at no time does Tyard dwell on the suffering of those who are transformed or the anguish of the mutational process. Instead, his metamorphoses most often effect either a salvation (fable 1: Clytorie; fable 3: Selemne; fable 8: Narcisse, etc.) or a just punishment (fable 5: Phasis; fable 6: Araxe; fable 7: Inde, etc.); and in all instances they serve to benefit the greater good of humanity. In the end, then, the kind of intellectual uneasiness that emerges as Tyard figures the semiosic drift is more properly consistent with the tensionand crisis-ridden mannerist aesthetic first documented by art historians and literary critics like Arnold Hauser and Wylie Sypher. ${ }^{62}$

Thus through a fresh evaluation of the graphic metamorphoses in the Douze Fables we deepen not only our appreciation of Pontus de Tyard's multifarious writings, but also our understanding of the author's links to the Pléiade and the philosophical and aesthetic milieu of his day.

UNIVERSITY OF NORTH CAROLINA AT GREENSBORO

${ }^{60}$ The same reshaping is apparent in Tyard's adaptations of Ovid's Metamorphoses (in fables 1 and 9) and Philostratus's Images (fable 2).

${ }^{6 t}$ Martin, esp. 19-21 and 73-112. On the general association of metamorphosis with the baroque, see again Mathieu-Castellani. Clearly, the position I advance here disagrees strongly with that of critics like Michel Jeanneret who, based upon the theories of John Shearman, argues that the parameters of mannerism "stand in opposition to ... the metamorphic sensibility" (se situent aux antipodes de . . la sensibilité métamorphique; 8). In the present essay, I would press for a broader understanding of the style, one that reconciles the aestheric with the psychological.

${ }^{62}$ Hauser, 2:97-106; Sypher, 102. 


\section{Bibliography}

Ayim, Maryann. 1986. "Semiosis." In Encyclopedic Dictionary of Semiorics, ed. Thomas A. Sebcok, et al., 2:887-93. 2 vols. Berlin.

Baridon, Silvio F. n.d. [1950]. Pontus de Tyard (1521-1605). Pavia.

Campo, Roberto E. 1998. Ronsard's Contentious Sisters: The Paragone berween Poetry and Painting in the Works of Pierre de Ronsard. Chapel Hill.

Cave, Terence. 1973. "Ronsard's Mythological Universe." In Ronsard the Poet, 159-208. London.

1979. The Cornucopian Text. Oxford.

Chamard, Henti. 1939-1940. Histoire de la Pleiade, 4 vols. Paris.

Dubois, Claude-Gilbert. 1979. Le Maniérisme. Paris.

Eco, Umberto. 1990. The Limits of Interpretation. Bloomington.

Fenoaltea, Doranne. 1990. Du palais au jardin: L'architecture des "Odes" de Ronsard. Etudes Ronsardiennes 3. Geneva.

Ford, Philip. 1989. "La fonction de l'ekphrasis chez Ronsard. "In Ronsard en son IVe Centenaire: L'Art de poésie, ed. Yvonne Bellenger, et al., 2:81-89. 2 vols. Geneva.

1997. Ronsard's "Hymnes": A Literary and Iconographical Study. Tempe, AZ.

Friedlaender, Walter. 1973. Mannerism and Anti-Mannerism in Italian Painting. 1965. Reprint, New York.

Gombrich, E. H. 1948. "Icones Symbolicae: The Visual Image in Neo-Platonic Thought." Journal of the Warburg and Courtauld Institutes 11: 163-92.

Hall, Kathleen M. 1963. Pontus de Tyard and his "Discours Philosophiques." Oxford.

Hauser, Arnold. 1957. The Social History of Art. 2 vols. New York.
Jeanneret, Michel. 1997. Perpetuum Mobile: Métamorphoses des corps et des oeuvres. de Vinci à Montaigne. Paris.

Joukovsky, Françoise. 1984. "Temps et éternité dans les Hymnes." In Autour des "Hymnes" de Ronsard, ed. Madeleine Lazard, 53-82. Paris.

Krieger, Murray, 1967. "The Ekphrastic Principle and the Still Movement of Poetry; or Laokoön Revisited." In The Play and Place of Criticism, 105-28. Balrimore.

1992. Ekphrasis: The Illusion of the Natural Sign. Baltimore.

Kushner, Eva. 1972. "The Role of Platonic Symbols in the Poetry of Pontus de Tyard." Yale French Srudies 47: 12444.

1978. "Pontus de Tyard devant le pouvoir royal." In Culture et pouvoir au semps de l'Humanisme et de la Renaissance, Congress Marguerite de Savoie: 1974, ed. Louis Terreaux, 34648. Paris.

. 1982. "Le Rôle structurel du locus amoenus dans les dialogues de la Renaissance." Cahiers de l'Assorjation Internationale des Erudes Françaises 34 (May): 39-57.

-1986. "Le Rôle de la temporalité dans la pensée de Pontus de Tyard." In Le Temps et la durée dans la litterature au Moyen Age et à la Renaissance, ed. Yvonne Bellenger, 211-29. Paris.

.1996. "The Renaissance Dialogue and Its Zero-Degree Fictionality." In Fiction Updated: Theories of Fictionality, Narratology, and Poetics, 165-72. Toronto.

Lebc̀gue, Raymond. 1951. "La Pléiade et les Beaux-Arts." In International Federation for Modern Languages and Literatures: Atti del Quinto Congresso Insernazionale di Lingue et Letterature Moderne, 115-24. Florence. 
Le Caron, Louis, 1986. "Ronsard, ou de la Poësic." In Dialogues, ed. Joan A. Buhlmann and Donald Gilman, 257. 301. Geneva.

Lecercle, François. 1987. La Chimère de Zeuxis: Portrait poétique et portrait peint en France et en Italie da la Renaissance. Tübingen.

Martin, John Rupett. 1977. Baroque. New York.

Mathieu-Castellani, Gisèle, ed. 1980. La Mesamorphose dans la poésie baroque française et anglaise: variations et résurgences. Tübingen.

Mayer, Marcel. 1952. Le Chateau d'Anet. Paris.

Miernowski, Jan. 1984. "La Póssic et la peinture: Les Douze Fables de Fleuves ou fonsaines de Pontus de Tyard." Réforme, Humanisme, Renaissance 18: 12-22.

Nais, Helène. 1981. "Pour une notice lexicographique sur le mot 'métamorphose.." In Poétigues de la métamorphose, ed. Guy Demerson, et al., 1525. Saint-Etiennc.

Nash, Jerry C. 1993. "'Fantastiquant mille monstres bossus': Poetic Incongruities, Poetic Epiphanies, and the Writerly Semiosis of Pierre de Ronsard." Romanic Review 84: 143-62.

Ovid. 1929-1933. Metamorphoses. Trans. Frank Justus Miller. 2 vols. London.
Pausanias. 1933. Description of Greece. Trans. W. H. S. Jones. 6 vols. London. Pico della Mirandola, Giovanni. 1965. Hepraplus. Trans. Douglas Carmichael. In On the Dignity of Man, 63174. New York.

Plutarch. 1905. Plutarch's Essays and Miscellanies. Trans. and ed. William W. Goodwin. 5 vols. New York.

1936. The E at Delphi. In Plutarch's "Moralia." Trans. Frank Cole Babbitt. 14 vols. Cambridge, MA.

Raymond, Marcel. 1972. La Poésie franf̧aise et le manierisme 1546-1610(?). Philadelphia.

Ronsard, Pierre de. 1914-1975. CEuvres completes. Ed. Paul Laumonier et al. 20 vols. Paris.

Roussel, Pietre D. 1875. Histoire et description du Chateau d'Anet. Paris.

Shearman, John. 1967. Mannerism. London.

Sypher, Wylie. 1965. Four Stages of Renaissance Style. New York.

Tyard, Pontus de. 1578. Discours du temps, de l'an, et de ses parties. Paris.

1966. Euvres poétiques completes. Ed. John C. Lapp. Paris.

Weber, Henri. 1984. "La philosophie des Hymnes." In Autour des "Hymnes" de Ronsard, ed. Madeleine Lazard, 33-51. Paris.

Yates, Frances A. 1947. The French Academies of the Sixteenth Century. London. 